\title{
MODERNISMO LATINO-AMERICANO E CONSTRUÇÃO DE IDENTIDADES ATRAVÉS DA PINTURA
}

\author{
Maria Helena Rolim Capelato
}

Depto. de História - FFLCH/USP

\section{Resumo}

O texto tem como objetivo refletir sobre as representações visuais expressas em algumas obras de artistas plásticos latino-americanos, vinculados aos movimentos modernistas dos anos 1920 que, através da pintura, procuraram traduzir suas preocupações com a busca de identidades nacionais ou regionais.

\section{Pallavras-Chave}

Modernismo Latino-americano • Identidade Nacional • Pintura

\section{Abstract}

The text has as its goal to reflect about express visual representations in some of the Latin American plastic artists arts, linked to the modern movements from 1920, which through painting, looked into translating its concerns by the search of national on regional identity.

\section{Keywords}

Modernism • National Identity • Painting 
A maioria dos intelectuais e artistas, representantes do modernismo latino-americano dos anos 1920, viveu na Europa num momento de efervescência cultural que se intensificou no pós Primeira Guerra. Eles incorporaram novas idéias e técnicas a partir do contato com representantes das vanguardas européias de diferentes tendências.

O tema da identidade nacional ou regional está implícito nas obras de grande parte dos pintores modernistas da América Latina desse período. Pretendo analisar algumas de suas obras que expressam a preocupação com a busca de raízes.

A historiografia contemporânea tem registrado um forte interesse no que se refere à compreensão de construções de identidades em diferentes épocas. Os autores que se debruçam sobre o assunto reconhecem a dificuldade de apreender o que seja identidade, traçar suas fronteiras, determinando os mecanismos de sua criação e contínua elaboração, partindo do pressuposto de que, assim como as culturas não são estanques, nem homogêneas, as representações identitárias são, na sua essência, híbridas, heterogêneas e mutáveis.

Meu interesse neste estudo não se restringe à caracterização de identidades nacionais. Se por um lado me refiro a situações específicas no âmbito das nações de origem dos pintores que explicam as suas preocupações identitárias, por outro, me interesso, especialmente, pela atuação desses intermediários culturais nos processos dinâmicos de circulação internacional que lhes permitiu apropriar-se de idéias e imagens produzidas em outros espaços, reelaborandoas de forma particular. Esse produto novo, por sua vez, se integra ao circuito internacional onde é reproduzido de diferentes maneiras por diferentes agentes. A recepção de um imaginário que representa uma identidade específica extrapola, portanto, os quadros nacionais.

A escolha da pintura como objeto desta análise se deveu à percepção da importância que certas obras tiveram no que se refere à representação de identidades nacionais ou regionais nessa época. Dawn Ades, autora de Arte na América Latina, dedica um capítulo do livro ao "Modernismo e a busca de raízes", no qual expõe e comenta a pintura de diversos artistas da região. A autora afirma que as transformações radicais por que passaram as artes visuais na Europa durante as primeiras décadas do século XX entraram na América Latina como parte de uma vigorosa corrente de renovação, começada nos anos 1920. Esses movimentos europeus, no entanto, não entraram como estilos já prontos e individualizados, mas foram, em geral, adaptados segundo as idiossincrasias, o espírito inovador de cada artista. Quase todos os que abraçaram o modernismo o 
fizeram no estrangeiro. $\mathrm{O}$ fato de ser americano, porém, marcou a obra até mesmo daqueles que eram internacionalistas dos mais convictos ${ }^{1}$.

A reflexão em torno de certas obras pictóricas me obrigou a pensar na relação do historiador com esse tipo de documento. Alguns autores me ajudaram nesse percurso: Manuel Antonio Castiñeras González no seu livro, Introducción al método iconográfico, afirma que a análise das imagens não é mais patrimônio da História da arte e que os intercâmbios interdisciplinares têm se mostrado muito positivos porque permitem um diálogo produtivo entre a palavra e a imagem ${ }^{2}$.

A imagem representa personagens, natureza, objetos e também mitos, acontecimentos históricos, além de representações da sociedade, da política e da cultura em diferentes contextos.

A iconografia refere-se ao conhecimento e à descrição das imagens. A relação entre o texto/imagem e o contexto permite captar a variação dos significados das imagens.

O método de análise desses documentos reporta-se à perspectiva intrínseca da obra, o que pressupõe análise do conteúdo, e à perspectiva extrínseca, que leva em conta as circunstâncias de tempo, lugar, biografia do artista, determinações sociais, culturais, intelectuais da época.

A obra deste autor se revelou especialmente importante para a reflexão a ser apresentada neste texto porque, além apresentar instrumentos necessários para a compreensão de termos e conceitos próprios da linguagem iconográfica, Castiñera Gonzáles se preocupa em refletir sobre o papel da arte como meio de transmissão de formas e idéias.

Mas há diferentes maneiras de se olhar um quadro, como mostra Susan Woodford. Alguns ilustram uma história com clareza, outros representam uma alegoria e há também os que expressam algo que não é reconhecível, apresentando uma estrutura abstrata ${ }^{3}$. O leitor poderá notar que, nas pinturas a serem apresentadas mais à frente, nos deparamos com imagens bem distintas: algumas retratam claramente uma cena, enquanto outras apresentam estruturas

\footnotetext{
${ }^{1}$ ADES, Dawn. Arte na América Latina. São Paulo: Cosac \& Naify Edições, 1997, p. 135.

${ }^{2}$ CASTIÑEIRAS GONZÁLEZ, Manuel Antonio. Introducción al método iconográfico. Barcelona: Ariel, 1998, pp.9-10.

${ }^{3}$ WOODFORD, Susan. Como mirar um quadro. Barcelona: Gustavo Gilli, 1983.
} 
mais complexas, o que não significa a impossibilidade de compreensão do relato contido na obra.

Alberto Manguel comenta que as imagens encerram um texto a ser lido de muitas maneiras. Para o autor, as imagens, tanto quanto os relatos escritos, nos brindam com informações necessárias a qualquer processo de pensamento. Ao citar Aristóteles afirmando que a "alma nunca pensa sem uma imagem", conclui que as imagens captadas pela vista tem significados variados: tanto se constrói uma linguagem feita de imagens traduzidas em palavras, como de palavras traduzidas em imagens, através das quais procuramos captar e compreender nossa própria existência. As imagens que compõem nosso mundo são símbolos, signos, mensagens e alegorias.

A imagem de uma obra de arte existe entre percepções: entre o que o pintor imaginou e o que pôs na tela; entre o que podemos nomear e o que os contemporâneos do pintor podiam nomear; entre o que recordamos e o que aprendemos, ou seja, as interpretações são múltiplas. Cada obra de arte se desenvolve atravessando incontáveis camadas de leituras e cada leitor tem que retirar essas camadas para chegar à obra a partir de suas próprias condições ${ }^{4}$.

A partir desta constatação de que uma obra de arte comporta múltiplas leituras, pretendo analisar o conteúdo das obras pictóricas escolhidas, entendendo-as como documentos de cultura, produzidos nesse contexto histórico que se caracterizou por uma renovação artística muito significativa.

O movimento denominado genericamente de "modernismo" foi liderado por um conjunto de artistas intelectuais que se dispuseram a propor inovações em relação à arte em vários países da América Latina.

\section{Modernismo na Europa e na América Latina}

Cabe inicialmente caracterizar os significados mais genéricos dos movimentos de vanguarda europeus relacionados ao modernismo latino-americano.

O modernismo europeu data de uma época anterior - últimas décadas do século XIX. Segundo alguns autores que se propuseram a definir o termo modernismo, ele se refere à arte da modernização que está relacionada ao progresso material, econômico, tecnológico dessa época.

\footnotetext{
${ }^{4}$ MANGUEL, Alberto. Leyendo imágenes. Uma história privada del arte. Bogotá: Editorial Norma, 2002, pp. 17-31.
} 
O artista do final do século expressava uma tensão e uma incerteza frente a mudanças que redefiniram as relações sociais e produziram novas concepções de mundo. O período se caracterizou por uma mescla de euforia e desespero, esperança no futuro e niilismo, revolucionarismo e conservadorismo, louvor e desprezo à tecnologia. Ou seja, as reações frente às mudanças não eram as mesmas e variavam do extremo otimismo ao extremo pessimismo nostálgico ${ }^{5}$.

Tal processo deu ensejo a transformações importantes no campo das artes e a circulação de imagens produzidas pelo espetáculo do progresso aproximou artistas num plano internacional.

Na literatura, o primeiro modernismo correspondeu ao momento em que os artistas procuraram superar o realismo/naturalismo, o romantismo e as representações humanistas, incorporando um estilo, uma técnica e uma forma capaz de expressar uma busca interior profunda.

O primeiro movimento modernista latino-americano, ou mais especificamente hispano-americano, acompanhou as mudanças artísticas européias, fazendo delas uma leitura particular. Como os europeus, os literatos desta região, se posicionaram de forma crítica em relação aos valores e códigos do mundo burguês, mas propuseram renovações literárias específicas: eles defenderam a criação de uma linguagem diferenciada da ex-Metrópole. A busca de uma identidade própria assumiu a língua como traço fundamental de ruptura com os padrões culturais da Espanha, que permaneceram mesmo após a independência das colônias.

O movimento data da década de 1880, mas antes já existia uma procura de formas para expressar a experiência americana. Essa busca, no entanto, ficou restrita a algumas experiências isoladas, segundo Jean Franco ${ }^{6}$. A partir dessa época, houve um renascimento literário hispano-americano que resultou em transformações na forma e no conteúdo, tanto da poesia como da prosa. A recusa da cultura espanhola aproximou os modernistas da França, ou melhor, de Paris, centro cultural do mundo ocidental.

O segundo movimento modernista da América Latina (a presença dos brasileiros, neste caso, foi significativa), diferentemente do anterior, contou com a participação de artistas plásticos que mantiveram contato com artistas euro-

\footnotetext{
${ }^{5}$ BRADBURY, Malcolm e MCFARLANE, James. Modernismo. Guia geral. São Paulo: Companhia das Letras, 1989.

${ }^{6}$ FRANCO, Jean. Cultura moderna en América Latina. México/Barcelona/Buenos Aires: Editorial Grijalbo, 1985.
} 
peus de diferentes nacionalidades: a pintura, sobretudo, assumiu importância tão relevante quanto a literatura. Caracterizou-se por uma busca de construção da identidade nacional que levou os artistas intelectuais ao encontro das tradições e raízes nacionais.

Refiro-me aos "artistas intelectuais" porque os modernistas dos anos 1920 abriram um amplo debate de idéias sobre a natureza da arte e sua relação com a nacionalidade. Além da produção artística, escreveram manifestos, criaram revistas, tiveram ampla participação na grande imprensa e se preocuparam em refletir sobre a sua sociedade, os impasses e possibilidades de mudança com ênfase no campo cultural.

Os movimentos modernistas latino-americanos dessa época foram tributários das experiências artísticas européias que, a partir da Primeira Guerra, introduziram elementos novos no campo das artes. O conflito mundial provocou uma crise de consciência entre intelectuais e artistas europeus que sentiram necessidade de expressar suas idéias e sentimentos. Os movimentos denominados vanguarda se ampliaram e se fizeram acompanhar de uma profusão de escritos sobre a natureza da arte, sua finalidade e função social do artista.

Esse debate também ocorreu na América Latina. Segundo Jorge Schwartz, a crescente politização da cultura latino-americana no final dos anos 1920, reintroduziu a discussão sobre o uso da palavra "vanguarda", através da clássica oposição entre "arte pela arte" e "arte engajada", relacionada a uma controvérsia em torno do próprio estatuto da arte. Como mostra o autor, inicialmente restrito ao vocabulário militar do século XIX, o termo "vanguarda" acabou adquirindo na França um sentido figurado na área política.

Mas ao mesmo tempo em que as facções anarquistas e comunistas se apropriaram do termo como sinônimo de atitude partidária capaz de transformar a sociedade, o surgimento dos ismos europeus deu grande margem à experimentação artística desvinculada, em maior ou menor grau, de pragmatismos sociais. E embora as vanguardas artísticas tivessem por denominador comum a oposição aos valores do passado e aos cânones artísticos estabelecidos pela burguesia do século XIX e início do XX, elas se distinguiam entre si, não apenas pelas diferenças formais e pelas regras de composição, mas por seu posicionamento frente às questões sociais ${ }^{7}$. Esta observação geral do autor é intei-

\footnotetext{
${ }^{7}$ SCHWARTZ, Jorge. Vanguardas latino-americanas. Polêmicas, manifestos e textos críticos. São Paulo: Iluminuras/EDUSP/FAPESP, 1995, pp.34-5.
} 
ramente válida para caracterizar os pintores que se preocuparam com a busca de raízes: eles tinham essa preocupação comum, mas diferiam entre si, tanto nas posições assumidas frente ao tema da função social da arte, como no sentido estético. Além disso, alguns deles reviram suas idéias políticas ou artísticas ao longo de suas trajetórias.

Os grupos tornavam-se conhecidos a partir de revistas, exposições, conferências e manifestos. $\mathrm{O}$ debate acalorado que surgiu em torno do significado da arte pode ser recuperado nesses documentos que, em muitos casos, traduziam a natureza militante e polêmica desses movimentos.

Paulo Menezes se refere à "Era dos Manifestos" ao analisar a profusão de movimentos, tendências artísticas e disseminação de escritos sobre a arte na Europa. ${ }^{8}$ Os artistas plásticos integrantes das "vanguardas" tinham uma característica comum: a crítica à pintura naturalista e realista e a recusa à imitação das fórmulas herdadas do passado, sobretudo da herança grega e seu conceito de beleza que toma o homem como modelo de perfeição. Alguns se insurgiram contra os velhos temas, contra os métodos de expressão pictórica (inclusive a noção de perspectiva) e os materiais utilizados pelos artistas. Franz Marc afirmou: "As tradições são coisas belas, mas é preciso apenas criar tradições, não viver delas". Kandisky era contra a existência de regras para a criação e Malevich defendeu a idéia de que "a arte não deveria servir ao Estado, nem à religião, nem à história dos costumes, nem à representação dos objetos. Deveria viver por si e para si”. Naum Gabo, pai do construtivismo, também se opôs a esses usos da arte e ao seu caráter descritivo. Mas nem todos os vanguardistas se preocuparam apenas com o aspecto formal da arte. O expressionismo alemão, o surrealismo francês, embora diferentes em vários aspectos, tinham como denominador comum a preocupação social. Os expressionistas reagiram contra os horrores da Primeira Guerra e o mesmo fizeram os dadaístas, ainda que de forma diversa; os surrealistas pregaram a transformação do homem através da libertação das formas do inconsciente e o futurismo reagiu fortemente contra a burguesia da época e contra a arte passadista; o cubismo o acompanhou em vários aspectos. ${ }^{9}$

Os artistas latino-americanos se inspiraram em várias dessas correntes, mas pretendo mostrar que mesmo os discípulos dos defensores da arte pela

\footnotetext{
${ }^{8}$ MENEZES, Paulo. A trama das imagens. São Paulo: EDUSP, 1997.

${ }^{9}$ SCHWARTZ, Jorge. Op. cit., p. 35.
} 
arte, não se identificaram com essa perspectiva. A maioria deles revelou preocupação com os problemas da sociedade a que pertenciam. Procuraram romper com o passado, mas a produção nova, geralmente, representou respostas a suas inquietações sociais e/ou políticas.

As propostas inovadoras se expressavam, particularmente, nos Manifestos que tinham um sentido panfletário e apresentavam uma estrutura literária telegráfica, contundente e sonora. Tendia mais a sacudir, provocar do que a suscitar reflexão. Como observa Jorge Schwartz, a retórica contida nesses documentos é agressiva e se volta para a promoção de uma nova estética. Vários foram produzidos por ocasião do lançamento de revistas e explicitavam o projeto cultural ou político-cultural que orientaria a trajetória dessas publicações ${ }^{10}$.

O auge da produção de Manifestos, tanto na Europa como na América Latina, se deu a partir dos anos 1920. Nesse período, houve uma efervescência política e social que se fez acompanhar de intensa produção artística. Não só a Primeira Guerra e suas conseqüências devastadoras, mas também a Revolução Russa e o início dos movimentos de esquerda e de extrema direita provocaram uma reavaliação dos valores estabelecidos a partir de novos parâmetros: a guerra revelou o absurdo da condição humana e a Europa passou a ser vista como o "velho mundo" em decadência enquanto a imagem do "novo mundo", lugar do futuro se fortaleceu. Houve febril intercâmbio de idéias e imagens entre esses dois continentes.

Na América Latina, alguns movimentos tiveram maior repercussão do que outros. Antes mesmo da eclosão da Primeira Guerra, o Manifesto Futurista de Marinetti (1909) tivera grande impacto na região. Ali se encontrava a negação mais radical ao passado, antigo e recente, e a apologia do futuro, da tecnologia e do movimento. A exaltação do novo por parte dos futuristas correspondia à imagem, que seria reforçada posteriormente, da América como lugar do futuro.

Alguns autores consideram que a repercussão desse Manifesto na América Latina pode ser tomada como o marco inicial do Movimento Modernista. Jorge Schwartz se refere a várias interpretações em torno dessa periodização e menciona o fato de que outros autores entendem a Semana de Arte Moderna de 1922 (São Paulo) como um divisor de águas na cultura e nas artes do continente latino-americano. O crítico uruguaio Angel Rama o definiu como um evento histórico que marca o ingresso oficial das vanguardas na América Latina.

${ }^{10}$ SCHWARTZ, Jorge. Op. cit. 
É importante lembrar como aconteceu esse evento, no qual ocorreram exposições, recitais de poesia, concertos musicais e conferências, que foram alvo de críticas acerbadas na ocasião.

O escritor e diplomata Graça Aranha, que morou na Europa entre 1900 e 1921, foi o seu promotor. Ele convivera com a agitação intelectual e artística do período e incorporara concepções estéticas do "espírito moderno".

Quando voltou ao Brasil em 1921, trouxe a notícia do "Congrès de l'Esprit moderne" que seria realizado, na Europa, por iniciativa dos dadaístas e puristas em 1922. O evento não aconteceu, mas inspirou a organização da Semana de Arte Moderna paulista programada para comemorar o centenário da independência.

Considerada marco do modernismo latino-americano, ela contribuiu para o desenvolvimento de pesquisas formais e de uma nova linguagem artística em relação a várias artes. A partir dessa experiência, surgiram, em todos os cantos do Brasil, revistas culturais; algumas delas lançaram manifestos que exaltaram a integração do país no mundo da técnica e da mecânica.

Quanto ao final do Movimento, há um certo consenso em admitir que, no início dos anos 1930, já se vislumbrava o ocaso das experiências inovadoras e experimentais ${ }^{11}$.

\section{Modernismo latino-americano e a busca de raízes}

Levando em conta a diversidade da produção cultural dessa época, considero mais apropriada a referência a movimentos modernistas latino-americanos, diversidade essa que se explica pelas diferenças conjunturais e históricas.

Nos anos 1920, a América Latina foi palco de conflitos sociais e políticos relevantes, alguns de caráter mais geral e outros mais específicos, como a Revolução Mexicana que teve grande impacto na América. Nesse período deuse, em vários países, a criação de partidos comunistas, ocorreram movimentos operários e estudantis de grande porte, além de movimentos nacionalistas de esquerda e de extrema direita. No plano intelectual, foram formuladas propostas de unidade latino-americana e houve significativo debate em torno da questão indigenista. Todos esses acontecimentos tiveram, cada um à sua maneira, repercussão importante. Foi nesse contexto que ocorreram redefinições no

${ }^{11}$ SCHWARTZ, Jorge. Op. cit., p.31-2. 
campo cultural com propostas de novos códigos artísticos para interpretar o mundo em mudança.

É importante lembrar, também, que nas primeiras décadas do século XX, foram organizadas comemorações relacionadas aos centenários de independência em muitos países. Tais comemorações deram ensejo a reflexões em torno dos problemas nacionais e busca de soluções para eles, o que explica, em parte, as tentativas de revisão das identidades nacionais.

A busca de uma identidade nacional fundamentada em novas bases coincidiu com o surgimento dos movimentos modernistas dos anos 1920. Literatos e artistas plásticos se inspiraram nas vanguardas européias da época, mas a busca de raízes nacionais implicou num processo de releitura da produção externa a partir das questões que estavam postas nos diferentes países da América Latina.

A tentativa de recuperação das origens foi, geralmente, orientada por uma valorização da cultura popular e das tradições. Com base nesses elementos, os modernistas pretendiam criar um produto novo a partir de novas linguagens artísticas aprendidas na Europa. A circulação de idéias e formas visuais entre os artistas latino-americanos e europeus possibilitou a existência de "diálogos através de imaginários"12.

A maioria dos modernistas dos anos 1920 criticava a cópia ou a imitação de padrões estrangeiros, comprometendo-se a produzir uma obra totalmente autêntica e original. No entanto, como observam alguns autores como Angel Rama, o "novo" significava, acima de tudo, uma vontade de ser diferente dos antecessores e nada dever ao passado.

O decantado produto novo era, na verdade, fruto de releituras do passado e a originalidade nacional resultava, muitas vezes, de uma inspiração européia. O contato dos modernistas latino-americanos com os europeus era intenso e ambos demonstraram interesse pelos mitos indígenas ou pelos ritos afro-antilhanos. Cabe lembrar que, desde o final do século XIX, artistas eu-

\footnotetext{
${ }^{12}$ A expressão foi usada recentemente por Jorge Schwartz, que realizou um trabalho de exposição pictórica acompanhada de um texto explicativo, através do qual estabelece relações entre o pintor modernista argentino Xul Solar - um dos que escolhi para análise - e pintores brasileiros (Ismael Néri, particularmente, Vicente do Rego Monteiro, Emiliano Di Cavalcanti, Antonio Gomide, Lasar Segall). O trabalho resultou no Catálogo Xul Solar. Imaginários em diálogo, que acompanha o Módulo integrante da exposição Xul Solar. Visões e revelações, apresentada na Pinacoteca do Estado de São Paulo - 24 de setembro a 30 de dezembro de 2005.
} 
ropeus lançaram os olhos para fora da "velha Europa" com o intuito de encontrar novos estímulos para a criatividade.

O processo de circulação entre o nacional e o internacional que caracterizou os movimentos modernistas latino-americanos foi permeado por uma tensão existente entre o prestígio dos modelos externos e a procura de uma identidade nacional. O cubano Alejo Carpentier, autor de $O$ século das luzes e O recurso do método, dentre outros, afirmou: "Temos que tomar nossas coisas, nossos homens e projetá-los nos acontecimentos universais para que o cenário americano deixe de ser uma coisa exótica”. O modernismo tentou por em prática essa idéia e por isto se pode dizer que, muitos deles foram, ao mesmo tempo, nacionalistas e cosmopolitas.

Foi com os representantes das vanguardas do "velho mundo" que artistas do "novo mundo" discutiram e compartilharam idéias, aperfeiçoaram suas técnicas e inventaram novas formas de expressão.

O novo foi um vocábulo muito utilizado na época. Appolinaire em L'Esprit nouveau e lês poètes, consagrou a ideologia do novo na esfera das artes, no que foi seguido por modernistas latino-americanos. Mas, como veremos mais à frente, a nostalgia da sociedade que não existia mais era visível em alguns escritores e artistas da América Latina. Na região, o culto ao novo e ao presente, traduzidos na exaltação da máquina, da tecnologia e do progresso, convivia, no mesmo espaço, com o culto nostálgico da sociedade que a modernização destruíra.

\section{A pintura como expressão de identidade nacional/regional}

Dentre os pintores latino-americanos que participaram de movimentos modernistas nos anos 1920, alguns revelaram nítida preocupação com a busca de raízes nacionais ou regionais (sul-americana ou latino-americana). A escolha dos artistas plásticos referidos nesta análise se orientou por esta característica ${ }^{13}$.

Os uruguaios Joaquim Torres-Garcia e Pedro Figari, o argentino Xul Solar, a brasileira Tarsila do Amaral e o mexicano Diego Rivera são, a meu ver, os mais representativos dessa tendência. Todos eles tiveram importância sin-

\footnotetext{
${ }^{13}$ Para a construção deste tópico consultei ADES, Dawn. "O modernismo e a busca de raízes”. In Arte na América Latina. São Paulo: Cosac \& Naify, 1997.
} 
gular no desenvolvimento das artes plásticas, não só em seus países de origem; além disso, suas obras foram reconhecidas externamente. Participaram de exposições internacionais nos principais centros de cultura da época, representando a arte latino-americana.

A atuação desses pintores junto aos movimentos modernistas se deu de diversas formas: algumas obras tinham como finalidade primeira ilustrar capas ou páginas de livros de literatos de destaque; outras integravam, juntamente com palavras, a composição de cartazes de exposições ou de Manifestos que definiam a trajetória de certos grupos. Dentre as inúmeras revistas editadas nesse período, várias delas foram ilustradas com reproduções de pinturas de artistas modernistas. Jorge Luis Borges, por exemplo, teve vários de seus textos ilustrados pelo pintor Xul Solar.

Inicio a apresentação das pinturas com uma obra que considero extremamente significativa no que se refere à busca de uma identidade regional.

O pintor uruguaio Joaquim Torres-Garcia, em uma de suas obras intitulada "O norte é o sul", virou o mapa da América do Sul de ponta cabeça e com relação a essa imagem, afirmou: "Nós temos idéia da nossa verdadeira posição, nos vemos, não como o resto do mundo gostaria de nos ver" (Fig.1).

A obra expressa, não apenas o desejo de definir uma identidade própria, rompendo com a tradicional dependência do sul em relação ao norte, mas também o dilema de muitos artistas latinoamericanos relacionados à seguinte questão: como produzir uma arte não colonizada.
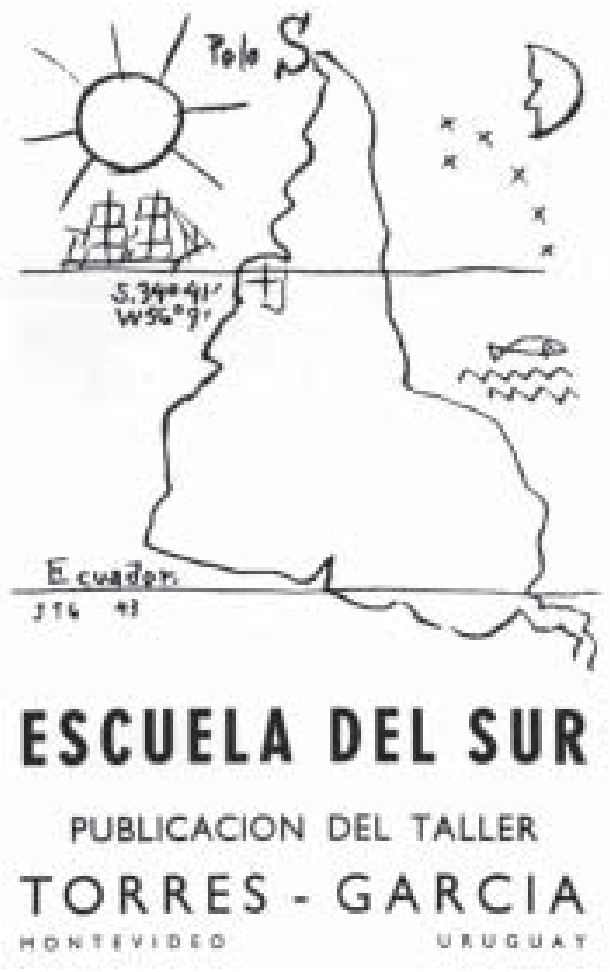

Figura 1

Joaquín Torres García. O Norte é o Sul, espólio do artista, Nova Iorque. 
É importante levar em conta que o artista mudou-se para a Espanha com a família quando tinha 17 anos, circulou pela Europa e Estados Unidos, e só voltou para o Uruguai em 1934, quando tinha 60 anos. Pertenceu ao movimento construtivista, cujo fundador foi o russo Naum Gabo que se opunha a qualquer aspecto descritivo da pintura e sua relação com outros aspectos da vida além da arte.

Em 1935, Torres-Garcia afirmou que o tempo do colonialismo e das importações terminara no que dizia respeito à cultura. Tinha fé no internacionalismo, mas sua obra revela um forte sentido do nacional e suas relações com a América Latina. Fez trabalhos inspirados nas civilizações pré-colombianas.

Construiu um "monumento cósmico", provavelmente inspirado na teoria da "raça cósmica" formulada pelo intelectual mexicano José Vasconcelos que pregava a integração das raças numa escala planetária, movimento esse já iniciado na América pré-colombiana, segundo o autor. A obra de Torres-Garcia se localiza num parque de Montevideo, denominado Rodó.

Assim como o pintor uruguaio, artistas ligados ao movimento modernista brasileiro tiveram grande contato com representantes das vanguardas européias. Este foi o caso, por exemplo, de Tarsila do Amaral, uma das mais expressivas representantes do modernismo no Brasil dos anos 1920. A artista não participou da "Semana de Arte Moderna" de 1922 porque estava na Europa, mas quando voltou ao Brasil, junto com o literato Oswald de Andrade, integrou-se no movimento modernista. $\mathrm{O}$ casal teve uma participação decisiva na renovação cultural brasileira.

O grande evento, já mencionado anteriormente, ocorreu em São Paulo e significou a primeira manifestação pública das pretensões vanguardistas. Mas cabe aqui abrir um breve parêntese para explicar porque ele aconteceu na cidade paulistana.

O significativo desenvolvimento cafeeiro ocorrido em São Paulo, entre o final do século XIX e as primeiras décadas do XX incentivou o progresso material do estado que, indiretamente favoreceu o desenvolvimento industrial e urbanização acelerada. Nesse contexto, a cidade de São Paulo se projetou como grande centro urbano, no qual conviviam ex-escravos e imigrantes estrangeiros mal assimilados às novas condições da vida urbana e fabril. O conflito urbano não tardou a se manifestar nesse espaço de identidades mutantes. Os políticos responsáveis pela chamada "velha República", segundo seus críticos, não conseguiam solucionar os problemas políticos e sociais, 
e eram impermeáveis aos sinais dos novos tempos, estando mal integrados no cenário da modernização contemporânea.

Não só São Paulo, mas o país se modernizava nessa época. As mudanças provocaram novas análises sobre o país. Os "íntérpretes do Brasil” passaram a fazer uma revisão em relação aos diagnósticos sobre a realidade, até então, muito marcada pelas teses raciais.

Cabe lembrar que, a partir do final do século XIX e início do século XX, inúmeros autores, literatos inclusive, haviam construído análises sobre os males do Brasil, imputando o "atraso" do país à presença de raças inferiores (índios, negros e mestiços) e, por esse motivo, defendiam a vinda de imigrantes europeus para "branquear" a sociedade. Mas as mudanças sociais ocorridas no país e a contestação das teses racistas e sua desmistificação como ciência, produzida pela Antropologia e outras áreas do conhecimento, no plano internacional, contribuíram para que houvesse reinterpretações sobre os problemas brasileiros a partir dos anos 1920.

A preocupação predominante dos que se propuseram, a partir de diferentes óticas, a repensar a realidade brasileira, passou a ser a falta de integração nacional (territorial, racial, social e cultural). Foi nesse contexto que a mestiçagem e seus componentes - índios e negros - começaram a ser valorizados; o "tipo nacional" até então depreciado frente ao estrangeiro, tornou-se alvo de interesse e sua incorporação à sociedade, vinculada à proposta de construção de uma nova forma de identidade nacional, se insere nos debates sobre a nacionalidade. Oswald de Andrade e Tarsila do Amaral participaram deles.

Ambos aderiram ao movimento modernista, mas estavam menos preocupados com a renovação da arte brasileira e sua inserção no contexto internacional, embora fossem a favor dela, e mais voltados para a tentativa de mudança de consciência por parte dos intelectuais e artistas, no sentido de produzir uma nova cultura, expressão de uma nova forma de identidade nacional. Os dois manifestos - Manifesto da Poesia Pau-Brasil (1924) e Manifesto Antropófago (1928) - de autoria de Oswald de Andrade revelam a grande preocupação com a releitura do passado e com a revisão da cultura brasileira.

O primeiro foi publicado no jornal Correio da Manhã. Oswald exaltava a formação étnica do país composta por índios, negros e brancos. Segundo Jorge Schwartz, ele percebera, em Paris, que aquilo que os cubistas europeus procuravam na África e na Polinésia como suporte estético-exótico da arte moderna, sempre fez parte de seu cotidiano nos trópicos: o índio e o negro. Assim, descobriu o primitivo em sua própria terra, mas, além disso, valorizou a natureza, a história e elementos da cultura popular como o carnaval, a cozinha, 
mesclando referências a símbolos da modernização como a fotografia, a técnica, a máquina. Condenou a cópia, a imitação, privilegiando a criatividade.

No segundo, afirma Jorge Schwartz, a linguagem metafórica, humorística e o uso de aforismos caracterizam o estilo do documento. Propõe a descida antropofágica como um ato de consciência, sendo que o dilema entre o nacional e o cosmopolitismo se resolveria pelo contato com as revolucionárias técnicas da vanguarda européia e a percepção da necessidade de reafirmar valores nacionais em linguagem moderna. Oswald transforma o "bom selvagem" de Rousseau no "mau selvagem" devorador do europeu e capaz de assimilar o "outro" para inverter a tradicional relação colonizador/colonizado. A antropofagia é considerada um ato religioso através do qual o índio incorpora atributos do inimigo, eliminando as diferenças. O Manifesto contém uma releitura da História do Brasil que começa com a deglutição do bispo Pero Fernandes Sardinha pelos índios Caetés de Alagoas. A descoberta do Brasil, segundo o texto, pôs fim a uma "sociedade comunista" onde prevalecia o direito natural. O autor propôs a "Revolução Caraíba", após a francesa, a russa e a surrealista, como a última das utopias. Esta seria a resposta ao colonizador europeu; o aforismo "tupi or not tupi" criado por ele como paródia da célebre dúvida hamletiana, expressa a ênfase na criação de uma nova forma de identidade nacional. ${ }^{14}$

O Manifesto Antropófago, que resume as contradições brasileiras entre o moderno e o primitivo, a indústria e

\section{figura 2}

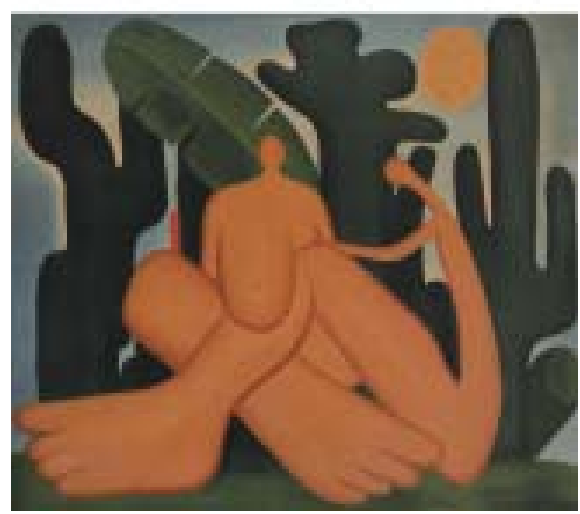

a natureza, a Europa e a América, foi publicado no primeiro número da Revista de Antropofagia, e ilustrado com um desenho de Tarsila do Amaral, onde se via uma figura nua de pés incrivelmente largos, alguns cactos e o Sol - idêntico motivo dessa pintura, intitulada Abapuru (que em tupi-guarani significa homem 'aba', que come 'puru'), seria reproduzida no ano seguinte, no quadro Antropofagia (Fig.2).

Tarsila do Amaral. Antropofagia (1929), óleo sobre tela, 1,26x1,42m. Fundação José e Paulina Nemirovsky.

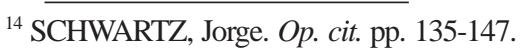


figura 3

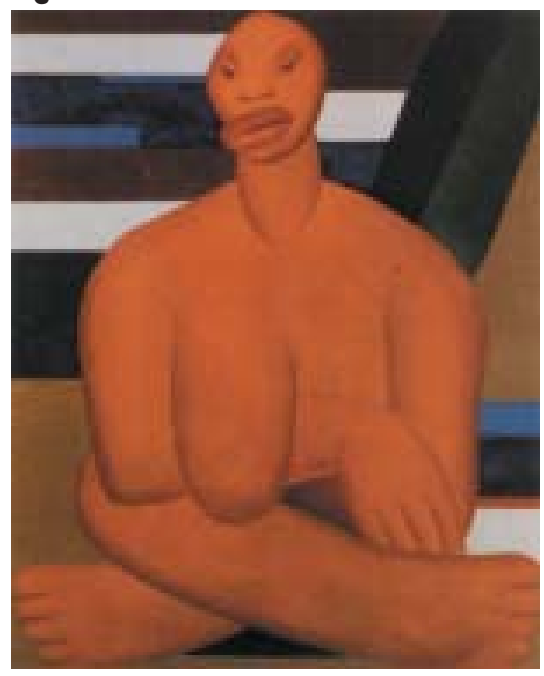

Tarsila do Amaral. A negra (1923), óleo sobre tela, 1,00x0,80m. Museu de Arte Contemporânea da Universidade de São Paulo.

Há uma outra obra da artista, $A$ negra (Fig.3), realizada em 1923, que prenuncia o estilo de Abapuru. Tarsila realizou este trabalho quando ainda estava vivendo na Europa e a pintura surgiu como ilustração da capa de um livro de poemas de Blaise Cendras; o poeta foi apresentado a ela por Léger, pintor que a inspirou em sua produção artística, bem distinta da que desenvolveu nestes dois trabalhos mencionados. ${ }^{15}$

Oswald e Tarsila voltaram ao Brasil em 1924 e nessa ocasião Blaise Cendras visitou o país. Juntos fizeram uma excursão pelas cidades históricas mineiras e partes do nordeste. Nessa viagem, Tarsila redescobriu o passa-
ular cultivada em pequenas cidades e do colonial brasileiro e a cultura popular cultivada em pequenas cidades e vilarejos. Tal experiência deixou marcas em algumas de suas pinturas.

Posteriormente Tarsila e Oswald de Andrade se tornaram simpatizantes da esquerda e suas concepções sobre a sociedade e o papel da arte se modificaram significativamente; em 1931, ela visitou Moscou e desde então suas pinturas incorporaram elementos do realismo socialista.

Mas na época anterior, ambos fizeram parte dos modernistas brasileiros, um grupo de elite que circulava pela Europa. Um crítico se referiu à volta de Tarsila ao Brasil, com seus vestidos do estilista Poiret e disposta a ensinar o povo a ser brasileiro. ${ }^{16}$

É importante assinalar que estes modernistas brasileiros buscaram construir a identidade nacional em novas bases, mas sua dívida em relação às vanguardas européias é inegável. A circulação deles entre os dois mundos contribuiu para uma produção cultural inovadora que não pode ser considerada, nem

\footnotetext{
${ }^{15}$ As duas obras foram comentadas no texto de ADES, Dawn. Op.cit., pp.133-4.

${ }^{16}$ ADES, Dawn. Op.cit., p. 134.
} 
genuinamente nacional, nem imitação do estrangeiro. O produto novo é fruto de um contexto específico que permitiu esse intercâmbio entre produtores culturais brasileiros e europeus.

$\mathrm{Na}$ Argentina dos anos 1920, os modernistas também tiveram papel renovador. Circularam também pela Europa, mas quando retornaram ao país, se depararam com outras questões.

Os argentinos viviam, nesse período, uma crise de identidade produzida pela presença massiva de imigrantes europeus que, desde o final do século XIX, mudou a fisionomia da sociedade Argentina e transformou a capital na cidade mais importante da América do Sul.

Buenos Aires, segundo Beatriz Sarlo era uma cidade cosmopolita do ponto de vista de sua população. O que escandalizava ou aterrorizava muitos dos nacionalistas do centenário (da independência), influía na visão dos intelectuais dos anos 1920. Na verdade, o processo havia começado muito antes, mas sua magnitude e profundidade continuavam impressionando os portenhos nesse período. A produção cultural traduzia, em termos ideológicos e morais, as reações frente a uma população diferenciada segundo línguas e origens, unida à experiência de um crescimento material rápido. Já em 1890 havia se quebrado a imagem homogênea da cidade, mas, como afirma a autora, trinta anos são poucos para assimilar, na dimensão da subjetividade, as radicais diferenças introduzidas pelo crescimento urbano, a imigração e inserção dos filhos de imigrantes na sociedade. Uma cidade que duplicou, em pouco menos de um quarto de século, a sua população sofreu mudanças que seu habitantes, antigos e novos, tiveram que processar. ${ }^{17}$

Nos anos 1920, graças a um crescimento educacional considerável, a cultura se democratizou em termos de distribuição e consumo. Nesse contexto de modernização urbana houve grande ampliação do público consumidor de cultura. A agitação cultural foi impressionante: ao longo da década foram criadas 80 revistas de cultura.

Os movimentos de vanguarda se impuseram e se manifestaram através de jornais e revistas e dentre outras se destacou a Martín Fierro. A vanguarda que circulou em torno dela tinha experiência européia, que seus representan-

${ }^{17}$ SARLO, Beatriz. Una modernidad periférica. Buenos Aires 1920 y 1930. Buenos Aires: Ediciones Nueva Visión, 1988, pp. 17-9. 
tes procuraram adaptar à realidade do país. O Manifesto, publicado para apresentação da revista, expressou o desejo de criar um ambiente artístico a partir de uma ação depuradora em relação ao passado (parnasianismo, simbolismo, etc.) e traduzir uma nova sensibilidade relacionada a uma nova compreensão da arte. O uso de vocábulos referentes a avanços tecnológicos era expressivo.

Os martinfierristas, apesar da exaltação do mundo moderno, admitiam o gaúcho como expressão da nacionalidade e valorizavam a cultura popular. Não por acaso, o título da revista se remete diretamente à obra Martín Fierro de José Hernandes, primeiro autor a traduzir, através da literatura, esse universo.

Segundo Jean Franco, a única obra latino-americana que chegou a cumprir esse papel renovador, antes do movimento modernista dos anos 1920, foi Martín Fierro, publicada em 1872. Seu autor criticou os governos europeizantes de Buenos Aires que tentaram destruir o modo tradicional de vida do gaúcho, cerne da nacionalidade e encarnação das qualidades da vida nos pampas. Conseguiu unir temas nacionais e universais e, valendo-se de imagens populares, canções, provérbios, poemas, procurou trabalhar com elementos da tradição argentina sem se basear em modelos europeus. Os escritores e o público culto da época desdenharam esse produto nativo que, posteriormente, foi valorizado pelos modernistas. Jorge Luis Borges considerou que este livro talvez tenha sido o mais importante da literatura Argentina em cento e cinqüenta anos ${ }^{18}$.

Participaram da revista Martin Fierro intelectuais e artistas com preocupações muito díspares como Jorge Luis Borges, Manuel Lugones, Leopoldo Marechal. Os pintores Pedro Figari e Xul Solar se integraram nesse grupo de modernistas argentinos.

Pedro Figari era Uruguaio. Exerceu, nesse país, a carreira de advogado e defensor público, foi eleito deputado em 1896 e indicado para vice-presidente. Fundou o jornal El Diário e publicou artigos sobre educação, direito e estética. Foi diretor da Escola de Belas Artes e Ofícios onde realizou profunda reforma sobre o ensino das artes, mas só começou a pintar com idade já avançada. Sua pintura foi rejeitada em seu país, fato que explica sua mudança para Buenos Aires em 1921. Foi na Argentina que abraçou definitivamente a carreira de pintor; ai se integrou às vanguardas artísticas.

\footnotetext{
${ }^{18}$ FRANCO, Jean Franco. Cultura moderna en América Latina. México/Barcelona/ Buenos Aires: Editorial Grijalbo, 1985, pp. 22-3.
} 
Xul Solar (Oscar Agustín Alejandro Schulz Solari) era filho de imigrantes ítalo-germânicos; aos dezesseis anos partiu a bordo de um navio cargueiro rumo à Europa onde conheceu a Itália, Alemanha, Inglaterra e França. Regressou à Argentina em 1924, quando se associou ao grupo martinfierrista.

$\mathrm{O}$ fato de pertencerem ao grupo martinfierrista é o elo de ligação entre eles; no mais, eram muito diferentes, apesar de demonstrarem preocupação com a busca de raízes nacionais ou regionais. Suas obras, como veremos a seguir, não revelam, do ponto de vista da forma ou do conteúdo, qualquer traço comum e, além disso, suas trajetórias de vida foram bastante distintas.

Quando Figari se radicou em Buenos Aires e Xul Solar voltou para o país, estava se firmando o movimento vanguardista argentino que tinha suas origens nas correntes literárias e plásticas européias, mas expressava uma vontade clara de independência intelectual e artística em relação ao estrangeiro. Figari tinha afinidade com os modernistas no que se referia à preocupação identitária: em sua busca de raízes, representou o gaúcho, concebido como essência da identidade rioplatense.

Embora ligado às vanguardas, idealizou o gaúcho procurando imortalizálo como um herói que merecia um monumento. Considerava esse nativo da América como um filtro de resistência à incorporação ao mundo moderno e reação à europeização desenfreada.

Sua pintura apresentava um tom nostálgico que contradizia a proposta dos modernistas de ruptura com o passado. Sua produção artística o aproximava do escritor Ricardo Guiraldes, com quem estabeleceu contato ao chegar a Buenos Aires. O autor do romance e best-seller, Don Segundo Sombra (1926), mitificava, às últimas consequiências, a figura do gaúcho e a vida no campo; alguns autores consideram a obra de Figari como o melhor exemplo pictórico desse texto literário.

Jorge Luis Borges afirmou que as figuras de Figari estavam fora do espaço e do tempo. As lembranças de sua juventude retratadas em seus quadros reafirmavam a história do homem rioplatense anterior à avalanche imigratória.

As imagens dos cavalos nos pampas em torno do Umbu, árvore enorme e inútil, mas que oferece sombra fresca ao cavalo e ao gaúcho cavaleiro, denotam a resistência às mudanças sociais na obra de Figari (Fig.4). A nostalgia do passado também se faz representar nas pinturas que retratam os costumes rurais e rastros da cultura africana trazidas pelos escravos; nelas aparecem casas antigas com pátios coloniais, festas de negros onde aparecem blocos de carnaval e rituais religiosos como o candomblé, danças populares acompanhadas por 


\section{figura 4}

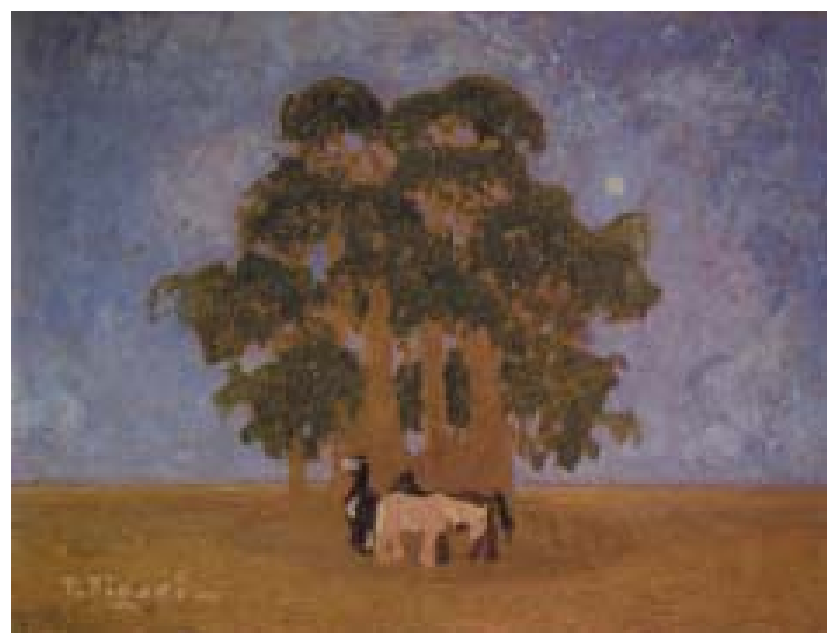

Pedro Figari. Cavalos nos pampas, (s/d), óleo sobre madeira, $62 \times 82 \mathrm{~cm}$. Coleção particular, Buenos Aires.

\section{figura 5}

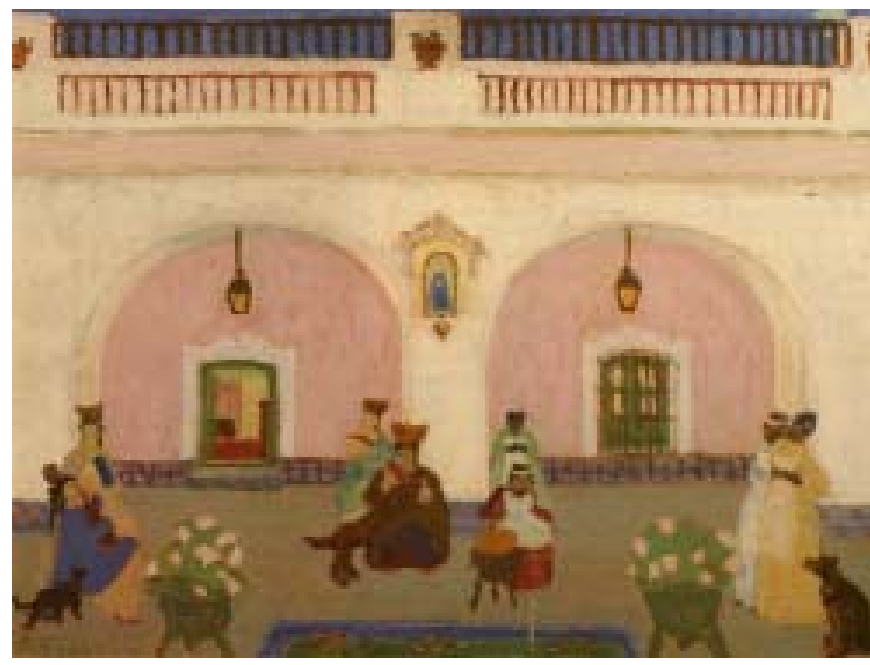

Pedro Figari. Dulce de membrillo, (s/d), óleo sobre papelão, $60 \times 81 \mathrm{~cm}$. Museu Nacional de Artes Plásticas, Montevidéu.

guitarras, tambores, reuniões sociais, funerais marcados por um ritual tradicional, cenas que contrastam com as reuniões frias e pomposas do "criollo" branco, com candelabros e retratos pendurados nas paredes (Figs. 5,6,7). 


\section{figura 6}

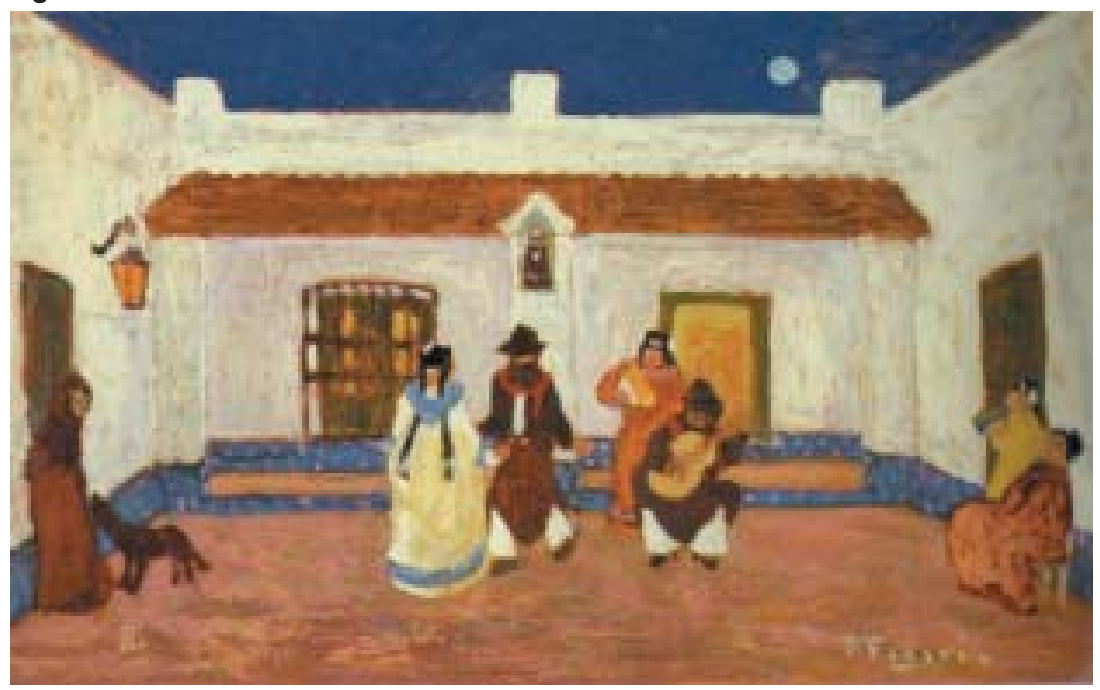

Pedro Figari. Dança de crioulo, (c.1925), óleo sobre papelão, 52,1x81,3cm. The Museum of Modern Art, Nova York. Doado pelo sr. e sra. Robert Woods Bliss.

\section{figura 7}

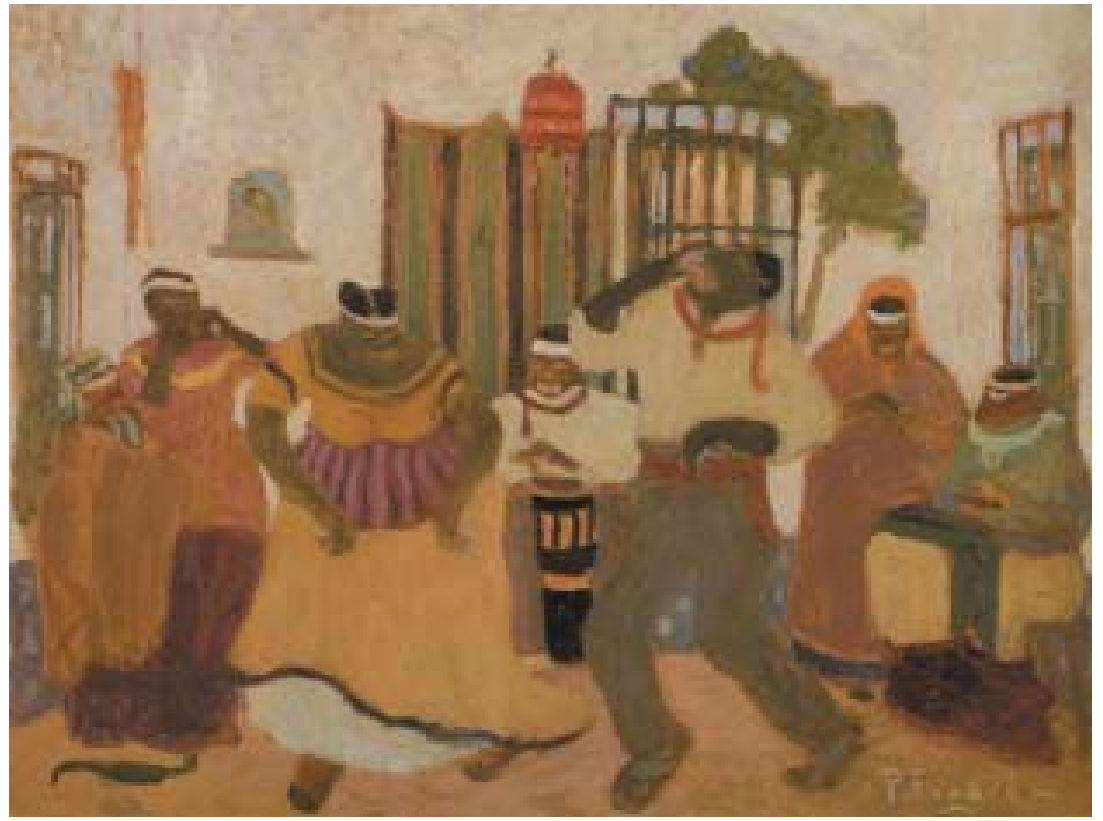

Pedro Figari. Nostalgias africanas, (s/d), óleo sobre papelão, 80x60cm. Museu Municipal Juan Manuel Blanes, Montevidéu. 
As suas pinturas expressam o sentido de um mundo desaparecido ou em vias de desaparecimento. O pintor preferia a natureza à civilização e não mostrava interesse pelas formas mais radicais da arte. Usava figuras decorativas, execradas pelos modernistas, colocando-as onde de fato existiam. Em 1930, publicou em Paris, História Kiria, onde apresentava um mundo utópico como crítica e sátira da sociedade contemporânea. O povo kiria desconhecia distinções de raça, não tinha superstições, não fazia a guerra, não tinha o sentido trágico da vida e ria da idéia de uma arte pela arte. ${ }^{19}$

Figari, como disse, fazia parte do movimento martinfierrista e colaborava na sua revista que, em 1925, promoveu uma exposição de arte moderna da qual ele participou junto com outros artistas argentinos como Petorutti, Curattela, Oliverio Girondo, Noah Borges, Xul Solar.

Entre 1925 e 1934 viveu na Europa e fez grande sucesso em Paris. Sua obra foi reconhecida por Paul Valéry, Jules Roman, Jean Cassou, James Joyce, Corbousier, Edouard Vuillard, Pierre Bonnard, Picasso, Léger, dentre outros.

Nessa ocasião (1926), o pintor uruguaio Rafael Barradas enviou uma carta a seu conterrâneo, Joaquim Torres-Garcia, onde anunciava a presença de Figari no continente, com o seguinte comentário: "Segue um caminho diferente do nosso, mas está indo muito bem (...). Já somos três pintores uruguaios na Europa”.

$\mathrm{O}$ autor Jorge Castillo comenta que o relacionamento de Torres- Garcia com Figari era conturbado, mas juntos fizeram, em 1930, uma exposição em Paris, da qual participaram outros artistas latino-americanos como José Clemente Orozco, Diego Rivera, Rego Monteiro.

Figari tinha uma visão pessimista da Europa, tida como decadente, e defendia a América, considerada, utopicamente, como reduto de tudo a ser preservado. Era admirador da modernidade, mas nunca pintou uma locomotiva, nem um carro, nem uma fábrica. ${ }^{20}$

Sua obra pictórica consolidou uma iconografia regional americana que expressa, de forma específica, um desejo de preservação das raízes, ao invés da construção de uma nova identidade a ser elaborada a partir dos valores do presente como pretendiam os modernistas em geral.

O pintor argentino, Xul Solar, também ligado ao modernismo e integrante do movimento martinfierrista, caracterizou-se por uma atitude frente ao

\footnotetext{
${ }^{19}$ ADES, Dawn. Op. cit., pp.137-41.

${ }^{20}$ CASTILLO, Jorge. A formação de um estilo. In: www.mnav.gub.uy/figari.htm.
} 
mundo e a arte muito particular. Era essencialmente místico e acreditava no horóscopo. Incorporou ao seu universo interior a meditação, a cabala, o budismo, o I Ching, além de mitos pré-colombianos e latino-americanos.

Em sua arte explorou, acima de tudo, temas místicos. Usava símbolos religiosos de diferentes culturas como a judaico-cristã, a chinesa, a hindu. A serpente, figura representativa em quase todas as religiões e filosofias, se impõe de forma obsessiva na sua obra. Nos seus quadros figuram, também, a estrela de Davi, cruz cristã, mandalas, cruz gamada, cabala, alquimia, arcanos do tarô, além de signos do zodíaco. Figuras humanas, misturadas com letras ou palavras de origem précolombianas ou criadas por ele, aparecem junto com símbolos laicos e místicos, misturados com representações do universo e serpentes (Figs. 8 e 9).

Não pertenceu a nenhuma vanguarda específica, mas incorporou aspecto de várias delas ao produzir uma obra considerada original. Os comentadores

\section{figura 8}

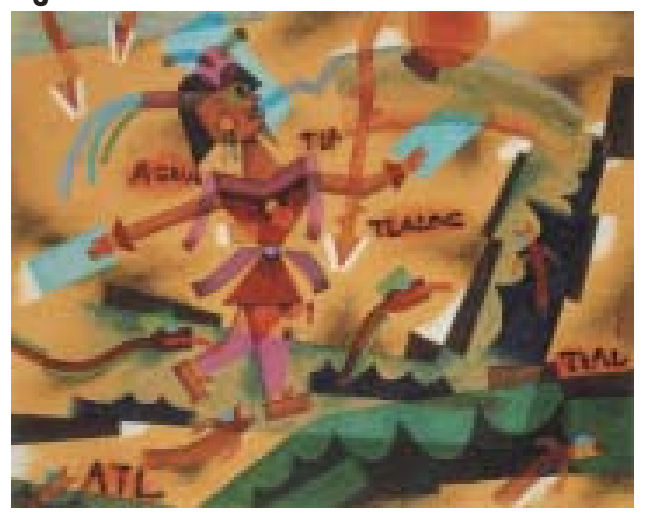

Xul Solar, Tlaloc (1923), aquarela sobre papel, 26x32cm. Coleção particular.

Xul Solar, Dança de Santos (1925), aquarela sobre papelão, $25 \times 31 \mathrm{~cm}$. Coleção Marion e Jorge Helft, Buenos Aires.

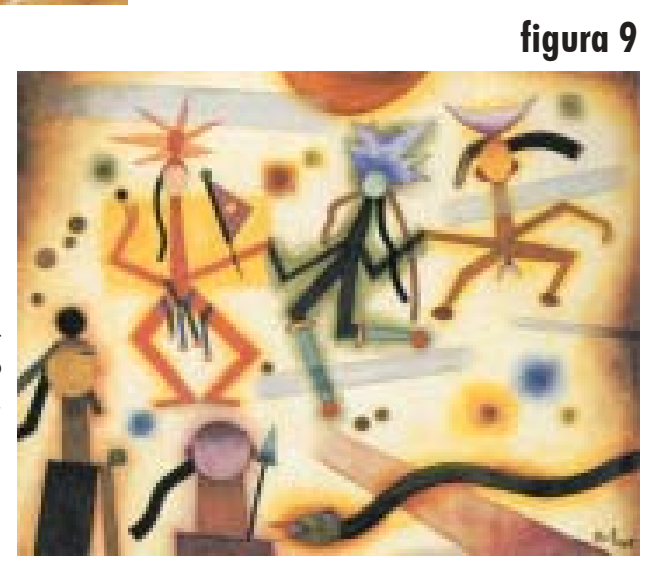


da sua produção apontam a relação delas com as pinturas de Klee e Kandinsky que também eram místicos.

Regressou à Argentina em 1924 e se associou ao grupo martinfierrista; na revista do grupo, sua obra aparecia com destaque. Esse artista, que ilustrou livros de Borges, era considerado pelo literato como expressão do homem cosmopolita, criador inigualável, que inventava sem cessar e não imitava jamais. Criou duas línguas: a panlíngua, e o neocriollo e inventou 12 religiões correspondentes aos 12 signos do zodíaco.

Sua obra não permite uma identificação clara com as questões referentes à "argentinidade". No entanto, Beatriz Sarlo afirma que sempre viu seus quadros como um quebra-cabeça de Buenos Aires, pois, mais do que sua intenção esotérica ou sua liberdade estética, a impressionaram sua obsessividade semiótica, sua paixão hierárquica e geometrizante, a exterioridade de seu simbolismo. Buenos Aires, completa a autora, nos anos 1920-30 era o enclave urbano dessas fantasias astrais e em suas ruas também se falava, desde o último terço do século XIX, uma panlíngua do porto imigratório. O que Xul mescla em seus quadros também se mescla na cultura dos intelectuais: modernidade européia e rioplatense, aceleração e angústia, tradicionalismo e espírito renovador, criolismo e vanguarda. Buenos Aires era o grande cenário latinoamericano de uma cultura de mescla, afirma a autora. ${ }^{21}$

Alguns comentaristas enfatizam o espírito cosmopolita do autor expresso, por exemplo, em uma de suas pinturas onde se destacam bandeiras de diferentes nacionalidades, incluindo as da Argentina, Brasil, Colômbia, México, Paraguai junto com as do Reino Unido, França, Estados Unidos e outras mais. Estes símbolos nacionais se mesclam com outros símbolos da cultura universal: serpente, sol, estrelas, cometa, seta, cruz e até esboços de figuras humanas (Fig. 10). Mas a preocupação com a identidade regional - sul-americana - foi identificada em outros campos de sua atuação.

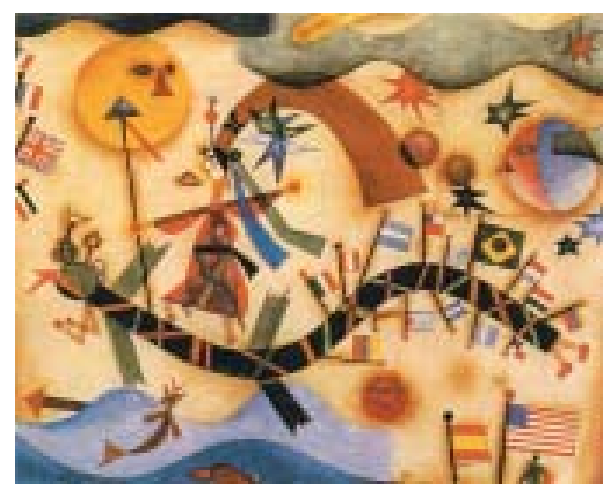

figura 10

${ }^{21}$ SARLO, Beatriz Sarlo. $O p$. cit., pp. 14-5.
Xul Solar. Drago. Aquarela sobre papel, 25,5x32cm. Museu Xul Solar. 
Jorge Schwartz, no texto Xul Brasil. Imaginários em Diálogo, já mencionado anteriormente, afirma que " $D$ a assombrosa geração latino-americana das vanguardas históricas dos anos 1920, Xul Solar foi o único que incorporou o Brasil em seu imaginário de forma sistemática. Suas pinturas, suas linguagens e sua biblioteca constituíram janelas abertas para a terra brasilis. Cinco décadas de intensa produção revelam um olhar, uma reflexão intelectual e mística voltada para o Brasil, assim como para o continente sul-americano".

$\mathrm{O}$ autor se refere a sua criação do neocriollo como uma língua artificial, composta basicamente do espanhol e do português que deveria servir ao diálogo entre as nações latino-americanas. Refere-se, também, ao fato de que em uma de suas viagens à Alemanha, trouxe consigo o livro Brasilien, escrito pelo alemão Adolf Bieler. Na sua biblioteca, composta por 3.500 obras, há registros de 58 títulos brasileiros, referentes a temas diversos como religiões afro-brasileiras, política e História brasileiras, Antropologia, Geografia, Lingüística, além de revistas de época como $O$ Cruzeiro, narrativas de viagem e inúmeros recortes de jornal referentes ao Brasil. Consta ainda de sua biblioteca o livro de poesia dos membros do grupo da revista Verde de Cataguases (1928), com dedicatória de Rosário Fusco, o romance A estrela do absinto (1927) de Oswald de Andrade, dois exemplares do primeiro número da Revista de Antropofagia (maio de 1928) e uma carta assinada pelo diretor da revista - Antonio de Alcântara Machado - convidando-o a se integrar ao grupo. Curiosamente, encontra-se, também, no acervo dessa Biblioteca, uma carta da Secretaria Geral da Educação e Cultura do Distrito Federal, informando a data e o horário de nascimento de Heitor Villa-Lobos. Jorge Schwartz comenta que a carta poderia ser uma resposta a um pedido de Xul para fazer o horóscopo do renomado músico brasileiro. O pintor revelou interesse, também, pelos integralistas Plínio Salgado e Gustavo Barroso; essa atenção talvez se explique pelo fato de que Plínio Salgado publicara, no primeiro número da Revista de Antropofagia, um extenso ensaio sobre A língua tupi, advogando o retorno à língua indígena como idioma nacional. A peça mais importante de sua biblioteca, certamente é Macunaíma, com dedicatória de Mário de Andrade, afirma Schwartz ${ }^{22}$. Como se pode notar, Xul Solar tinha grande interesse pelo movimento modernista brasileiro.

Os dois pintores da região platina, ligados ao movimento modernista argentino, apresentam características muito diferenciadas. Ambos circularam

${ }^{22}$ Idem, pp.4-5. 
pela Europa, tiveram influências externas e suas obras foram reconhecidas pelas vanguardas internacionais. A busca de raízes caracterizou a produção artística de Pedro Figari e Xul Solar, no entanto, as preocupações desses pintores com a identidade regional - rioplatensense ou sul-americana - partem de visões de mundo muito díspares.

O caso do modernismo mexicano, que passarei a tratar, apresenta características diferentes em relação aos exemplos anteriormente mencionadas. As particularidades mexicanas estão relacionadas, de maneira muito direta, com a conjuntura histórica da Revolução Mexicana, um dos acontecimentos mais importantes do país, que teve grande repercussão na América Latina.

A pintura muralista é a que melhor representa o modernismo mexicano nas artes plásticas. Ela constitui um exemplo a mais da diversidade que essa tendência artística latino-americana encerra, e sua característica peculiar no forte sentido social dessa arte.

Segundo Octávio Paz, a pintura mural foi fruto da Revolução mexicana, mas também da grande revolução estética européia ${ }^{23}$.

A Revolução teve início em 1910 e conquistou sua primeira vitória com a derrubada do regime de Porfírio Diaz, que permanecera no poder por várias décadas. No entanto, a consolidação do movimento foi difícil e lenta, passando por várias fases onde se degladiaram grupos de diferentes tendências; a sua periodização final é controversa, dependendo do tipo de interpretação que se dá ao movimento. Em 1917, representantes do grupo denominado constitucionalista assumiram o poder, após derrotar os exércitos camponeses comandados por Emiliano Zapata e Pancho Vila; nesse ano foi elaborada uma nova Constituição, mas os conflitos entre as lideranças políticas tiveram continuidade.

Quando Álvaro Obregón assumiu o cargo de Presidente em 1920, nomeou o intelectual José Vasconcelos como Secretário da Educação. O Secretário elaborou um programa de construção de murais e para a realização dessa grande obra, convidou os pintores Diego Rivera e David Alfaro Siqueros, que estavam na Europa atuando junto com as vanguardas artísticas. O convite foi extensivo a José Clemente Orozco que vivia no México, mas em contato intenso com a produção artística das vanguardas internacionais.

\footnotetext{
${ }^{23}$ PAZ, Octávio. "Pintura Mural e Revolução Mexicana". In México en la obra de Octávio Paz. III Los princípios de la vista. México: Fondo de Cultura Económica, 1987.
} 
O objetivo principal dessa produção artística era a representação de uma nova forma de identidade nacional voltada para as raízes do povo mexicano e para a cultura popular. Esses elementos culturais passaram a ser privilegiados após o final da Revolução. A proposta de José Vasconcelos era causar impacto visual através de representações que retratassem a cultura autóctone a partir de suas tradições, símbolos, mitos, ritos e expressões da vida cotidiana. O Secretário entregou a eles as paredes da recém-construída Escuela Nacional Preparatória (ENP).

Diego Rivera era um artista eclético que combinou vários estilos. Teve influência do cubismo, mas afastou-se dessa corrente, passando a estudar a obra de Cézanne, voltando à pintura figurativa; tinha afinidades com Gauguin e Rousseau em relação às cores e à representação das culturas "exóticas" (asiáticas, africanas, da Oceania e pré-colombianas). Quando foi convidado por Vasconcelos para produzir murais, viajou para a Itália com o objetivo de estudar as obras do Renascimento italiano, sobretudo a arte mural. Esta experiência aparece numa de suas primeiras pinturas murais - "A criação" - produzida entre 1922-1923 e localizada no auditório da ENP (Fig.11). Ela corresponde ao gosto de Vasconcelos que apreciava alegorias: apresenta dois planos distintos - no centro se destacam tipos humanos e outros caracteres da cultura mexicana - nas laterais e no alto, foram pintadas alegorias cívicas

\section{figura 11}

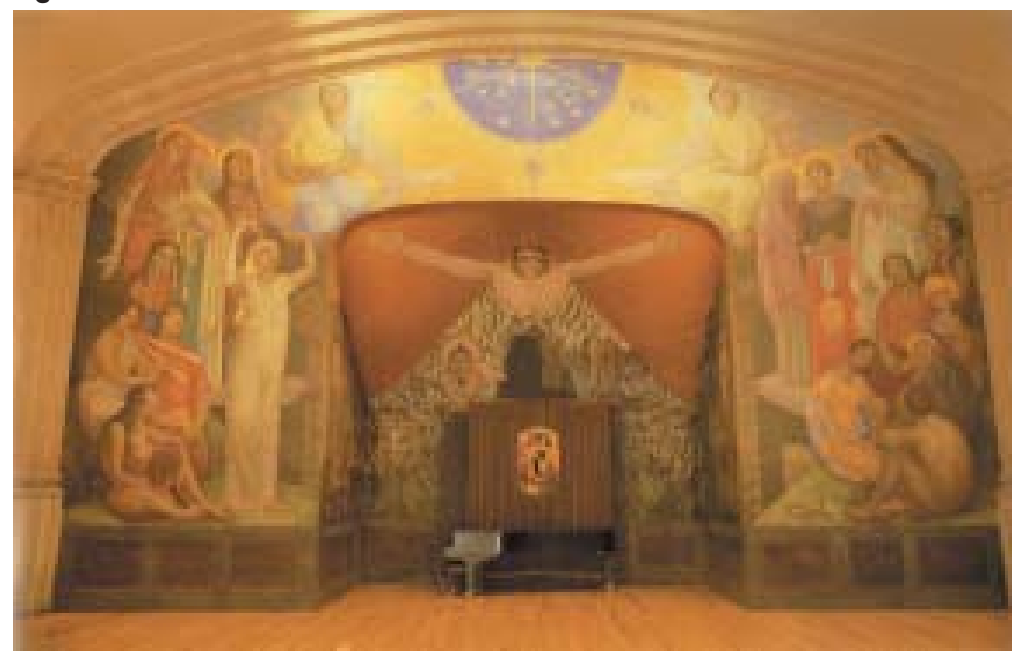

Diego Rivera. A criação (1922-1923), encáustica e folha de ouro. Anfiteatro Bolívar, Escuela Preparatoria Nacional, Cidade do México. 
(representações da justiça, esperança) e cristãs, claramente inspirados nas obras do renascimento italiano.

Durante o período em que os pintores estiveram ligados ao projeto cultural de José Vasconcelos (1920-1924), a volta às origens e o culto ao nacional deveriam ser privilegiados, mas esses temas só aparecem na obra de Diego Rivera.

Na pintura dos murais que decoraram o edifício da Secretaria de Educação Pública, recém construído, predominam as imagens do povo indígena, representado através de cenas da vida cotidiana, incluindo festas e rituais, representações do mundo do trabalho (Figs. 12 e 13). Há, também, uma série de pinturas encomendadas pelo Secretário, na qual aparecem mulheres vestidas com trajes típicos de cada uma das regiões do país. Todas elas são de autoria de Rivera.

\section{figura 12}

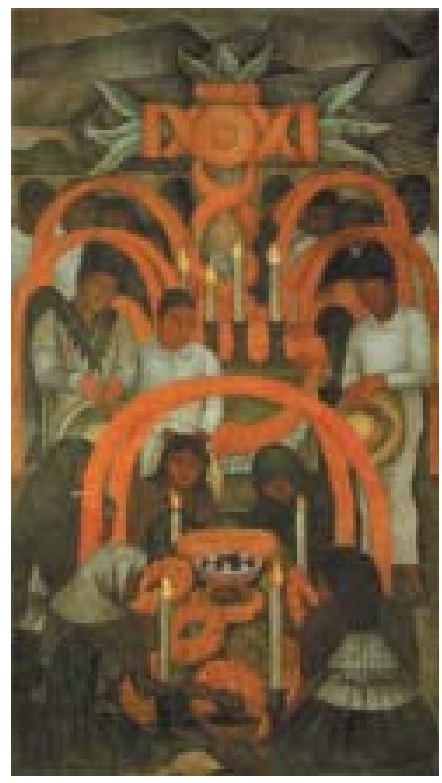

Diego Rivera. Del ciclo "Visión política del pueblo mexicano" (Patio de las fiestas). La ofrenda - Día de muertos (19231924), 4,15x2,37m. Planta baja, pared sur. Foto: Rafael Doniz.

\section{figura 13}

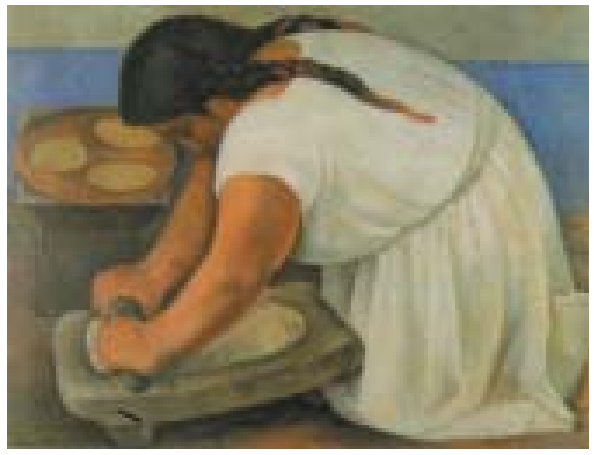

Diego Rivera. La molendera (1924), encáustica sobre lienzo, 106,7x121,9cm. Museo de Arte Moderno, MAM-INBA, Ciudad de México. Foto: Rafael Doniz.

No final do mandato de Obregón surgiram problemas políticos: em 1924, Vasconcelos renunciou ao seu cargo e os artistas, sem sua proteção, tiveram as encomendas dos murais suprimidas. Mas Rivera conquistou as simpatias do novo Secretário da Educação e pôde continuar o trabalho nesse edifício; nessa época, tanto ele quanto Siqueros, já eram militantes de esquerda. 
Siqueros tornou-se o mais radical, do ponto de vista ideológico, no entanto, em termos artísticos, era o mais comprometido com o modernismo no que se refere ao emprego das técnicas. Suas pinturas tinham forte conteúdo social, mas as obras relacionadas aos temas da Revolução são posteriores, ou seja, datam da década de 1950. Orozco produziu obras referentes a ela nos anos 1920, mas o pintor não se identificava com as causas políticas, nem se preocupou em retratar as origens da nacionalidade. Negava-se a pintar índios com sandálias e calças de algodão sujas e não aceitava fazer obra de propaganda. ${ }^{24}$

Rivera, quando se tornou militante de esquerda, passou a se orientar pela ideologia marxista. Em 1927 foi para Moscou e, influenciado pela iconografia da Revolução Russa, incorporou os símbolos da cultura comunista à sua pintura. Eles aparecem em vários murais, inclusive na parte final de sua obra que retrata a "Epopéia do povo mexicano" (iniciada em 1929), onde narra a história do México, desde o pré-hispânico até sua atualidade (Figs. 14,15 e 16).

Octávio Paz, crítico impiedoso de Rivera, definiu sua pintura como ideológica, didática, doutrinária e salientou que sua visão da história do México expressa nestes últimos murais, era dualista e maniqueísta.

Seus comentários a respeito da pintura de Siqueros são, ao contrário, bastante elogiosos apesar de desqualificar a ideologia política que norteia suas ações. Conclui que ele foi um artista importante, criativo e com capacidade de usar as técnicas novas de maneira original, diferentemente de Rivera. Enalteceu, também, a obra de Orozco e comentou que ele não tentara penetrar na realidade mexicana com as armas das ideologias.

Ao comparar a ideologia dos três pintores, referiu-se a Orozco como anárquico, a Siqueros como ortodoxo/dogmático e a Rivera como marxista oportunista. ${ }^{25}$

A apreciação de Octávio Paz sobre os pintores muralistas está comprometida com a posição que ele ocupava no cenário cultural mexicano da época. O literato pertencia ao grupo de vanguarda que girava em torno da revista Contemporâneos; eles defendiam a arte pura e o não compromisso do artista com interesses de qualquer natureza. Esse grupo foi combatido pelos artistas que se organizaram em torno do Sindicato Revolucionário de Obreros Técni-

\footnotetext{
${ }^{24}$ A propósito dos muralistas mexicanos, consultei ADES, Dawn. Capítulo 7, "O movimento muralista mexicano", op.cit., pp.151-77.

${ }^{25}$ PAZ, Octávio. Op. cit.
} 
Epopeya del pueblo mexicano, 1929-1935. Ciclo de frescos. Escalinata con 3 monumentales murales, superficie pintada: 410,47 $\mathrm{m}^{2}$. Palacio Nacional, Ciudad de México.

\section{figura 14}

Diego Rivera. México prehispánico - El antiguo mundo indígena (1929), $7,49 \times 8,85 \mathrm{~m}$. Vista total de la pared norte. Foto: Rafael Doniz.
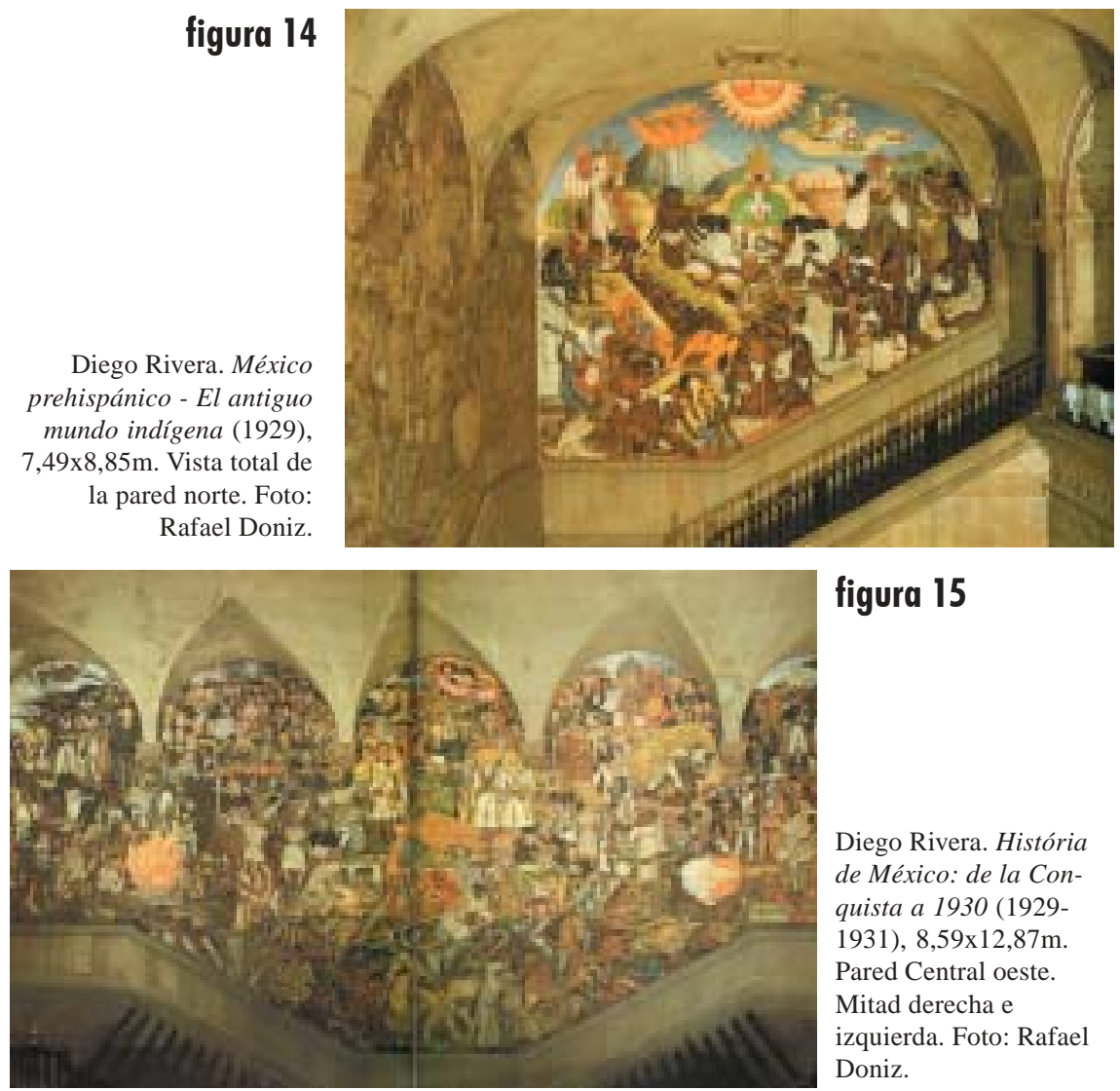

\section{figura 15}

Diego Rivera. História de México: de la Conquista a 1930 (19291931), 8,59x12,87m. Pared Central oeste. Mitad derecha e izquierda. Foto: Rafael Doniz.

\section{figura 16}

Diego Rivera. México de hoy y de mañana (19341935), 7,49x8,85m. Vista general de la pared sur. Foto: Rafael Doniz.

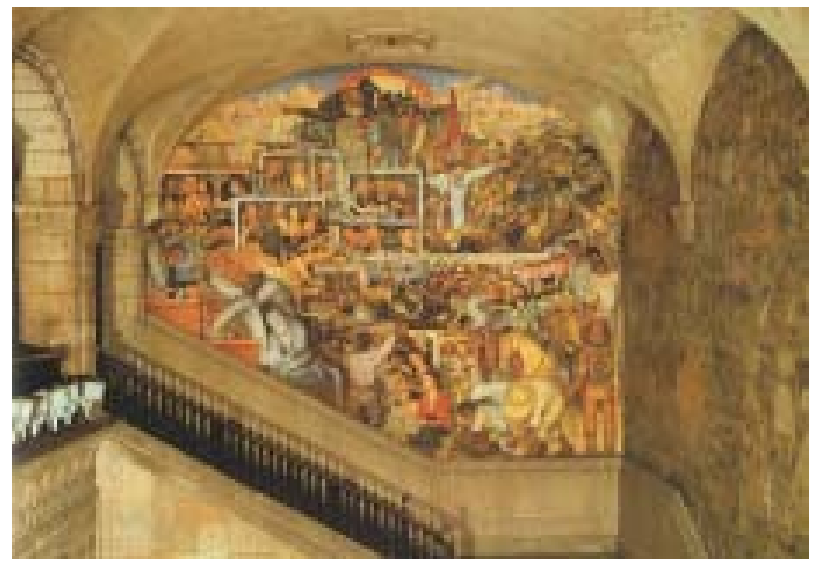


cos y Plásticos, devido à postura descompromissada que assumiam, considerada expressão do decadentismo burguês.

A experiência dos muralistas, apesar de orientada pelo tema da Revolução Mexicana, apresenta, não apenas formas, mas temáticas diversas.

Como procurei mostrar, os movimentos modernistas latino-americanos, embora orientados por perspectivas comuns apresentam características bem diversas. Mesmo os intelectuais e os artistas que se orientaram pela busca de raízes, expressa nas pinturas que aqui foram expostas e comentadas, apresentam diferenças significativas. Esta constatação permite concluir que o movimento foi plural e heterogêneo, tanto na sua forma como na visão de mundo e ideais que inspiraram os artistas que fizeram leituras particulares da conjuntura histórica na qual atuaram.

Essa diversidade, ao invés de diminuir a sua contribuição em termos sociais e culturais, atesta a importância desses movimentos. O intenso intercâmbio cultural que permitiu a interlocução entre latino-americanos e europeus, enriqueceu a produção artística da América Latina nesse período; ela foi produto de releituras originais das propostas européias realizadas a partir de filtros nacionais ou regionais.

As obras dos artistas mencionados conquistaram reconhecimento no exterior e exerceram influência recíproca entre os países da região. O movimento, no seu conjunto, permitiu a renovação do campo cultural.

A busca de raízes que significou tentativas de criação de novas formas identitárias, que são datadas, revela, no entanto, a preocupação dos artistas com os problemas enfrentados pelas respectivas sociedades onde atuaram.

Jean Franco, ao analisar a cultura moderna na América Latina, afirma que a arte latino-americana do final do século XIX a meados do século XX, se caracteriza por uma intensa preocupação social: o produtor de cultura, nesse contexto, se colocava na posição de consciência de seu país. A idéia da neutralidade do artista ou da pureza da arte, segundo a autora, teve poucos adeptos na região porque, como a integração nacional estava ainda em processo de definição e os problemas sociais e políticos eram imensos, o sentimento de responsabilidade do artista em relação à sociedade impedia que movimentos artísticos novos surgissem como solução a problemas meramente formais, como acontecia na Europa ${ }^{26}$, Os produtores culturais latino-americanos, ge-

${ }^{26}$ FRANCO, Jean. Op. cit., p.15. 
ralmente, criavam impulsionados por suas angústias face a mudanças significativas no quadro social ou face a problemas cruciais enfrentados pelas sociedades em que viviam. A busca de novas formas de identidade nacional/regional, na América Latina dos anos 1920, surgiu como tentativa de compreensão das transformações da época e dos desafios que elas colocavam para os que se sentiam responsáveis pelos destinos do mundo em que viviam.

\section{Referências Bibliográficas das Ilustrações}

ADES, Dawn. Arte na América Latina. São Paulo: Cosac \& Naify Edições, 1997. (figuras 1, 2, 3, 4, 5, 6, 7, 9).

Catálogo da Exposição Xul Solar - Visiones y Revelaciones. Museo de Arte Latinoamericano de Buenos Aires. (figura 8).

GRADOWCZYK, Mario Horacio. Alejandro Xul Solar. Buenos Aires: Ediciones Alber, Fundación Bunge y Born, 1994. (figura 10).

KETTENMANN, Andrea. Diego Rivera 1886-1957: un espíritu revolucionario en el arte moderno. Germany:Taschen, 1997. (figuras 11, 12, 13, 14, 15, 16) 